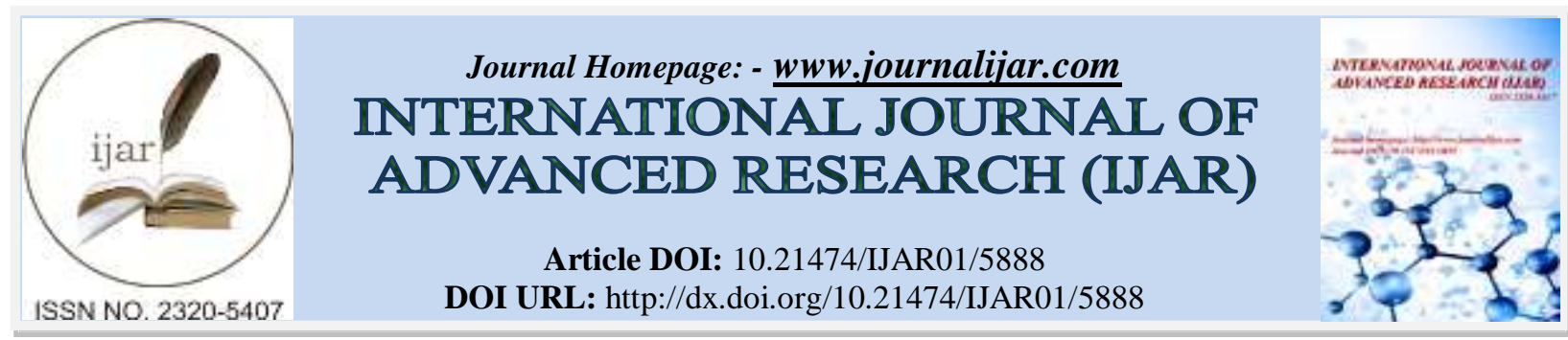

RESEARCH ARTICLE

\title{
CHANGES IN NEAR-SURFACE WIND SPEED IN THE SOUTH OF BENIN FROM 1961 TO 2016.
}

\section{Houngninou B. Etienne ${ }^{1}$, Allé C. S. Ulrich ${ }^{2}$, Guédjé K. François ${ }^{1}$ and Kougbéagbédè Hilaire ${ }^{1}$.}

1. Département de Physique, Faculté des Sciences et Techniques, Université d'Abomey-Calavi.

2. Chaire Internationale en Physique Mathématique et Applications (CIPMA - Chaire UNESCO), Faculté des Sciences et Techniques, Université d'Abomey-Calavi.

\section{Manuscript Info}

Manuscript History

Received: 16 September 2017

Final Accepted: 18 October 2017

Published: November 2017

Key words:-

wind speed, climate change, Beaufort's scale, West Africa, Benin.

\begin{abstract}
The trends of changes in the near-surface wind speed from 1961 to 2016 in the South of Benin have been analyzed based on anemometric data of the synoptic station in Cotonou. From the linear regressions and the application of Pettitt test, the decennial and interannual variabilities of the monthly and yearly average speeds have been analyzed. The results show a strong decrease of the wind between 1961 to 1977 and less between 1978 and 2008. Starting in 2009, the wind speeds increased due to the intensification of the wind during the first half of the year except for February. The changes in wind speed are mainly due to strong winds fluctuations.
\end{abstract}

Copy Right, IJAR, 2017,. All rights reserved.

\section{Introduction:-}

In the context of the current climate change, recent studies focused on the trends of temperatures and precipitations instead of changes in near-surface wind speed (Shenbin et al., 2006; Pryor et al., 2009). This fact has particularly been true in West Africa, partly because of the importance of precipitations for the economy and food safety in that region (Barbier et al. 2009; Sultan et al., 2012). However, changes in near-surface wind speed could have some important socio-economic and environmental consequences (Fallot, 2008; Guo et al., 2011). Zhou et al. (2006) have demonstrated that the decrease of the wind speed has caused the reduction in wind energy supply in the delta of Pearl River in China. The decrease of the near-surface wind speed would be the first factor responsible for the decrease of atmospheric evaporative demand on the Thibetan plateau (Shenbin et al., 2011) and in Australia (Roderick et al., 2007). Therefore, understanding changes in wind speed can help us understand climate changes better and its environmental, ecological and socio-economic, and impacts (Guo et al., 2011). Several studies have analyzed the trends of changes in near-surface wind speeds over these last 50 years in several regions of the world mainly in Europe (Brazdil et al., 2009; Pirazzoli et Tomasin, 2003; Smits et al., 2005), Asia (Guo et al., 2011; Zhang et al., 2007), America (Pryor et al., 2009; Tuller, 2004), Australia (McVicar et al., 2008, Roderick et al., 2007), Antartic (Aristidi et al., 2005; Turner et al., 2005) and Alaska (Lynch et al., 2004). For West Africa, less attention has been given to long period changes of the near-surface wind speed. Studies on near-surface wind speed mainly focused on lithometeors issues (Kalu, 1979; McTainsh, 1980; Chamard and Courel, 1988; Ozer, 1997). This study aims to document changes in near-surface wind speed in South of Benin from the anemometric data of the synoptic station in Cotonou (Benin).

Corresponding Author:- Houngninou B. Etienne.

Address:- Département de Physique, Faculté des Sciences et Techniques, Université d’AbomeyCalavi. 


\section{Data and methods:-}

\section{Study Area and Data used}

Benin is located in West Africa in the tropical area between $6^{\circ} 30^{\prime}$ and $12^{\circ} 30^{\prime}$ North latitude and $1^{\circ}$ and $3^{\circ} 40^{\prime}$ East longitude (Fig 1). Two masses of air, the monsoon and the harmattan, traverse Benin. Each becomes dominant depending on periods of the year (Gbaguidi et al., 2011). The monsoon is higher during the rainy seasons (MarchNovember). The harmattan is higher in the dry season (November-February). The average daily speed is roughly 4 $\mathrm{ms}^{-1}$ (Alle et al., 2013). Benin has a less hilly terrain particularly in the South with a vegetation destroyed by the anthropic activities (Gbaguidi et al., 2011).

The anemometric data used are the maximum daily near-surface wind speed, which were measured at $10 \mathrm{~m}$ above the ground. They derive from the synoptic station in Cotonou $\left(06^{\circ} 21^{\prime} \mathrm{N} ; 02^{\circ} 23^{\prime} \mathrm{E}\right)$, which is installed in the South of Benin on the Atlantic coast since 1952. However, it is only from 1961 that the frequent recordings of the wind speed started. That is the reason why the period from 1961 to 2016 has been chosen to undertake this study. It is considered as the possible longest period of recordings of the near-surface wind speed in Benin. These data show fewer gaps from 1961 to 2016 (less than 10\%). The gaps have been considered as missing data.

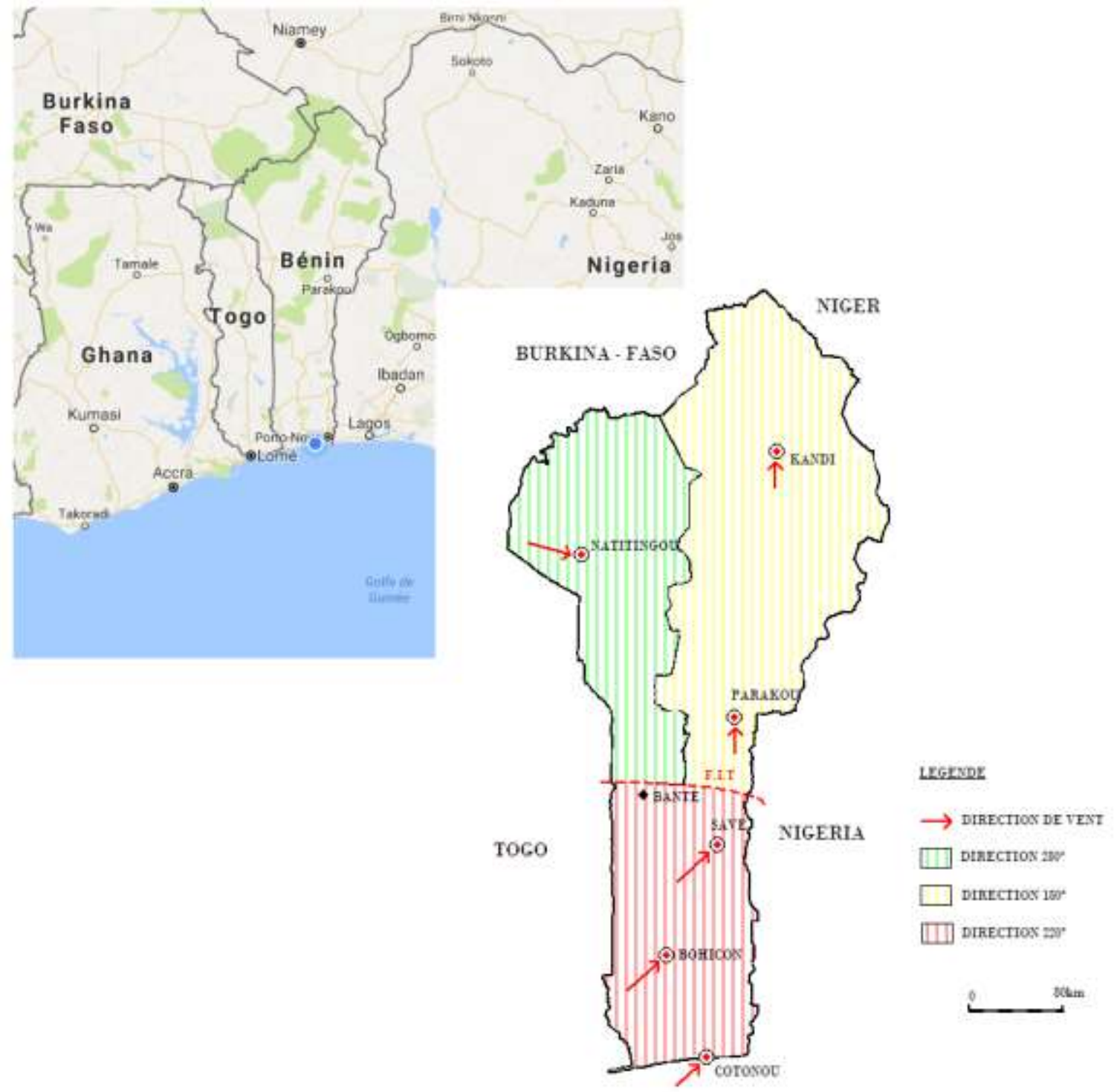

Fig 1:- Location of Benin in West Africa with the major direction map of the monsoon in Benin according to Gbaguidi et al., (2011) 


\section{Methods:-}

Changes in the wind speed on the annual scale

First, a chart based on the wind speed index has been used to visualize the interannual variability of the mean annual wind speed. The index of the wind speed has been calculated as shown by Lamb (1982) as a reduced centered variable (Eq.1). This means an excess (index $>0$ ) or a deficit (index $<0$ ) of the wind speed for the year under observation compared to the chosen period.

$I=\frac{V_{i}-\bar{V}}{\sigma}$

With, $V_{i}$ : mean annual wind speed of year i, $\bar{V}$ : mean interannual wind speed on the reference period (1961-2016) and $\sigma:$ standard deviation interannual on the reference period (1961-2016).

Next, Pettitt test (Pettitt, 1979) has been implemented in a recurrent way in order to identify a change in probability's law of the mean annual wind speed (breakage). Finally, the use of Mann-Whitney's test (Mann and Whitney, 1947) allowed us to compare the different sub-periods.

\section{Changing in wind speed on a monthly scale:-}

The analysis of the change in wind speed has been refined at monthly scale. In this respect, a linear regression has been done every month between the mean monthly wind speed and the years for each sub-period. The slopes of the linear regressions were used to verify the persistence at the monthly scale of the decennial trends.

\section{Change in the wind category occurrence:-}

Some wind speed categories have been made (Table 1) based on the Beaufort scale (Hirsch et al., 2016). For each sub-period, the occurrence of a category used corresponds to the ratio between the number of this category and the total number of observations made over the sub-period. The comparison of the occurrences between the sub-periods informs us on the changes in category occurrences.

Table 1:- Classification of the maximum daily near-surface wind speed in Cotonou based on Beaufort's scale

\begin{tabular}{|l|l|l|}
\hline Acronym & Beaufort's scale terms & $\begin{array}{l}\text { Wind speed interval } \\
(\mathbf{k m} / \mathbf{h})\end{array}$ \\
\hline C1 & Light air & $1-5$ \\
\hline C2 & Light breeze & $6-11$ \\
\hline C3 & Gentle breeze & $12-19$ \\
\hline C4 & Moderate breeze & $20-28$ \\
\hline C5 & Fresh breeze & $29-38$ \\
\hline C6 & Strong breeze & $39-49$ \\
\hline C7 & Near gale & $50-61$ \\
\hline C8 & Gale & $62-74$ \\
\hline C9 & Strong gale & $75-88$ \\
\hline
\end{tabular}

\section{Results:-}

Average features of the maximum daily near-surface wind speed in the South of Benin

The analysis of the distribution of the maximum daily near-surface wind speed shows that $90 \%$ of these winds are located between the interval ]4 $\mathrm{ms}^{-1}, 12 \mathrm{~ms}^{-1}$ ] (Fig 2), with an mean annual of $7.8 \pm 1.2 \mathrm{~ms}^{-1}$. They are higher from March to October with a landing at $8.5 \mathrm{~ms}^{-1}$ (Fig 3). 


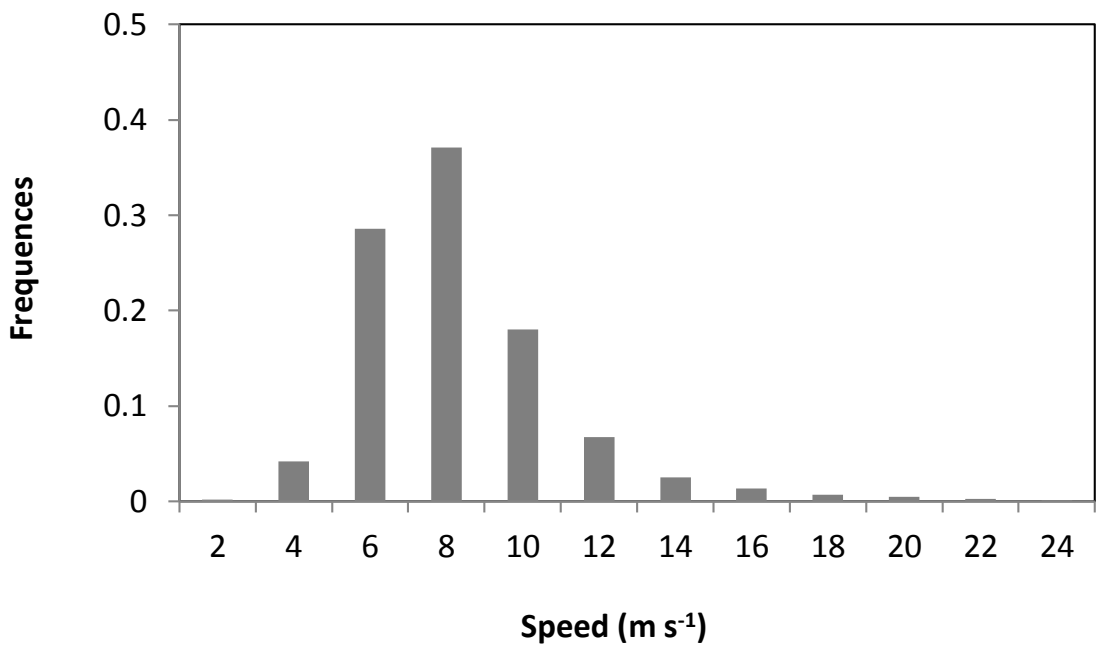

Fig 2:- Distribution of the maximum daily near-surface wind speed in Cotonou from 1961 to 2016

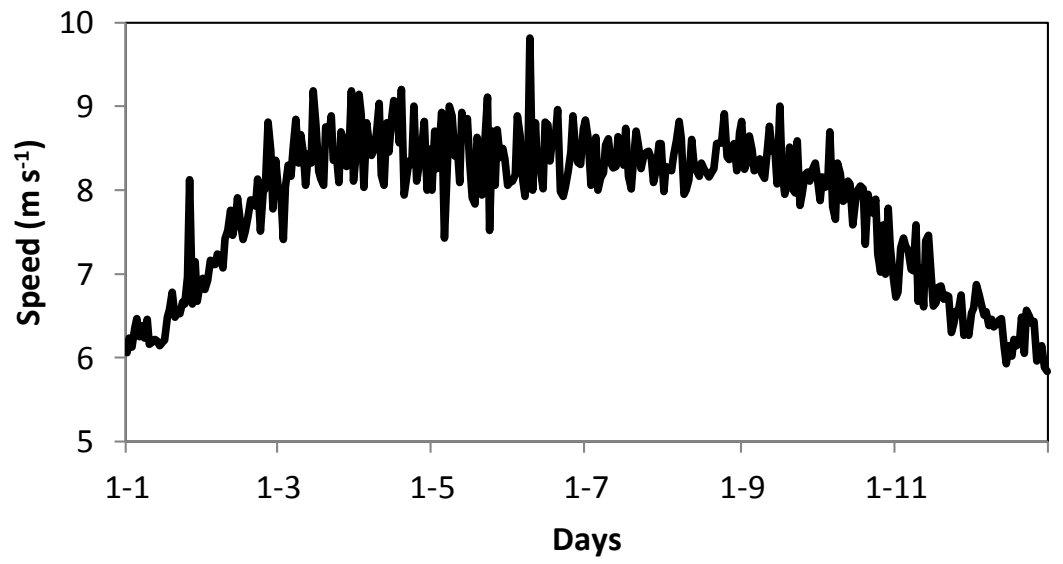

Fig 3:- Annual cycle (1961-2016), of the maximum daily near-surface wind speed in Cotonou

\section{Change in the annual scale of the wind speed:-}

The wind speeds show an important interannual variability to which the strong decennial variability is superposed (Fig 4). The recurring application of Pettitt test reveals a first breakage in 1977 and a second breakage in 2008. Thus, the evolution of the near-surface wind speeds in the South of Benin can be separated into three distinct subperiods: (i) 1961-1977 (P1), (ii) 1978-2008 (P2) and (iii) 2009-2016 (P3). Table 2 sums up the features of each of these sub-periods. The sub-period P1 is characterized by a speed excess of 13\% compared to the mean interannual $(1961-2016)$, with the highest interannual variability $(\mathrm{RSD}=0.11)$ over the three sub-periods. The sub-period P2 is characterized by a reduction of $22 \%$ of the wind intensities and a reduction of $27 \%$ of their interannual variability compared to the sub-period P1 (RSD = 0.08). During the sub-period P3, winds show a revival of about $36 \%$ with regards to P2 exceeding roughly 5\% the level of P1. The test results of Mann Whitney (Mann and Whitney, 1947) written in table 3 show that sub-period P2 is significantly different from sub-period P1 and P2 (p-value < 0.05). These results also show that the sub-periods $\mathrm{P} 1$ and P2 are not significantly different in terms of wind speeds (pvalue > 0.05). However, the comparative analysis of the sub-periods trends P1 and P2 clearly shows that these two sub-periods show reverse trends (Fig 5). In fact, the sub-period P1 is characterized by a progressive decrease of the winds (slope $=-0.15 \mathrm{~ms}^{-1} \mathrm{a}^{-1}$ ) that continued during the sub-period P2, but with a lower intensity (slope $=-0.03 \mathrm{~ms}^{-}$ ${ }^{1} \mathrm{a}^{-1}$ ). At the reverse, the sub-period P3 is characterized by a neat increase of the wind speeds with a slope inversely closer to that of P1 (slope $=0.11 \mathrm{~ms}^{-1} \mathrm{a}^{-1}$ ). 


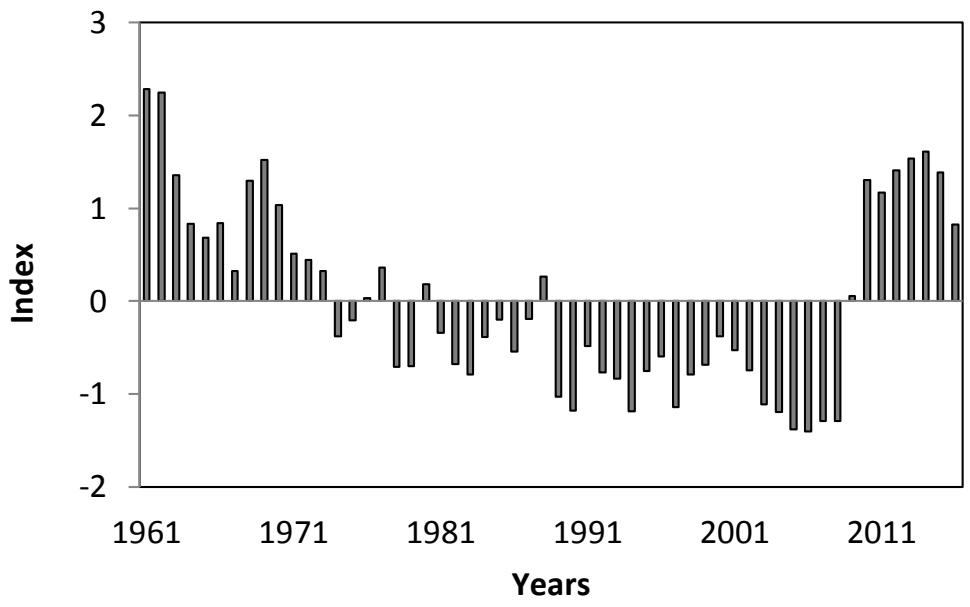

Fig 4:- Indexes of the mean annual of the maximum daily near-surface wind speed over the period of (1961 to 2016) in Cotonou

Table 2:- Feature of the sub-periods

\begin{tabular}{|l|l|l|l|l|}
\hline & $1961-1977(\mathrm{P} 1)$ & $1978-2008(\mathrm{P} 2)$ & $2009-2016(\mathrm{P} 3)$ & $1961-2016$ \\
\hline Mean $\left(\mathrm{ms}^{-1}\right)$ & 8.86 & 6.87 & 9.34 & 7.8 \\
\hline Standard Deviation & 0.99 & 0.56 & 0.66 & 1.2 \\
\hline $\begin{array}{l}\text { Relative Standard } \\
\text { Deviation (RSD) }\end{array}$ & 0.11 & 0.08 & 0.07 & 0.16 \\
\hline
\end{tabular}

Table 3:- Mann-Whitney test results, P1 = 1961-1977; P2 = 1978-2008; P3 = 2009-2016

\begin{tabular}{|l|l|l|l|}
\hline Sub-periods & P1 - P2 & P2 - P3 & P1 - P3 \\
\hline U & 515 & 2 & 41 \\
\hline U (normalized) & 0.000 & 0.000 & 0.000 \\
\hline Expectation & 263.500 & 124.000 & 68.000 \\
\hline Variance (U) & 2151,917 & 826.667 & 294.667 \\
\hline p-value (bilateral) & $<0.0001$ & $<0.0001$ & 0.124 \\
\hline alpha & 0.05 & 0.05 & 0.05 \\
\hline
\end{tabular}

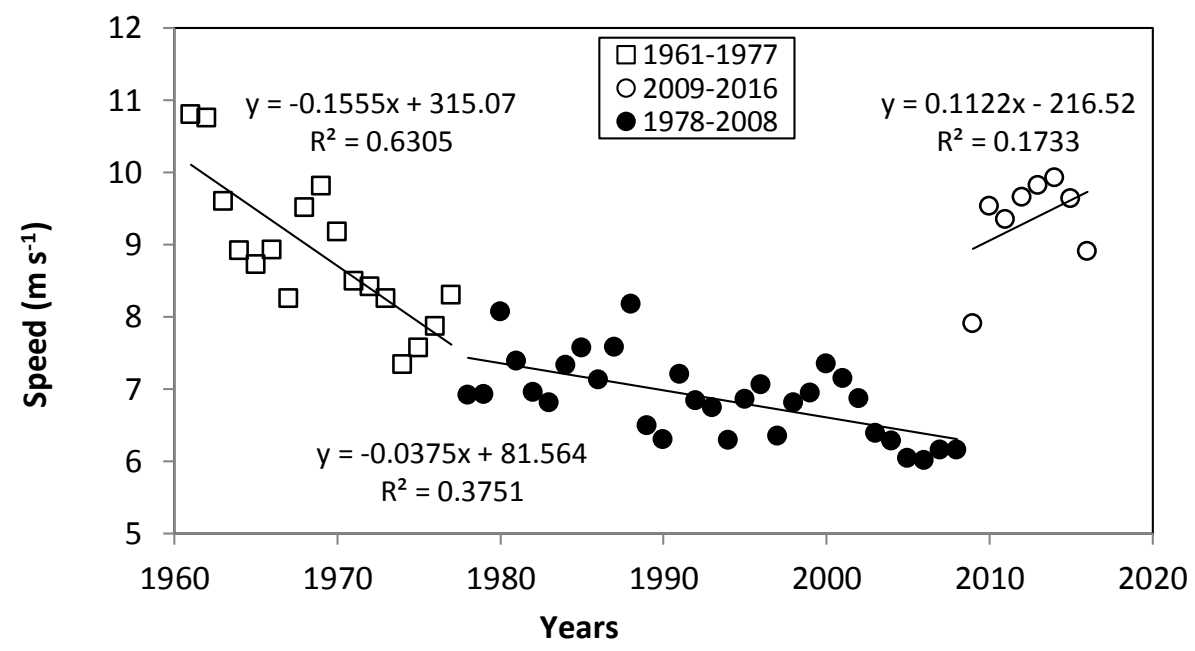

Fig 5:- Trends of the mean annual of the maximum daily near-surface wind speed in Cotonou over the period of 1961 to 2016. 


\section{Change in the monthly scale of the wind speed:-}

Fig 6 sums up the linear regression slopes between the mean monthly of the maximum daily near-surface wind speed and the years. After analyzing this Fig, it appears that all the months have been affected by the decrease of the winds (negative slopes) during the sub-period P1 and P2 in various proportions. The months between May and August are the months that have recorded the highest decreases (slope from -0.18 to $-0.21 \mathrm{~ms}^{-1} \mathrm{a}^{-1}$ ) during the subperiod P1. During the sub-period P2, this decrease of the winds has considerably slowed down on overall months as shown the quasi-null slopes observed. The sub-period P3 is characterized by an important increase of the winds over January to July except for February, whereas the decreasing trend is still persistent over the second mid of the year (August to December). The increase of wind speeds observed is observed between P2 and P3 on the yearly scale is due to the intensification of winds over the first mid half of the year, except for February.

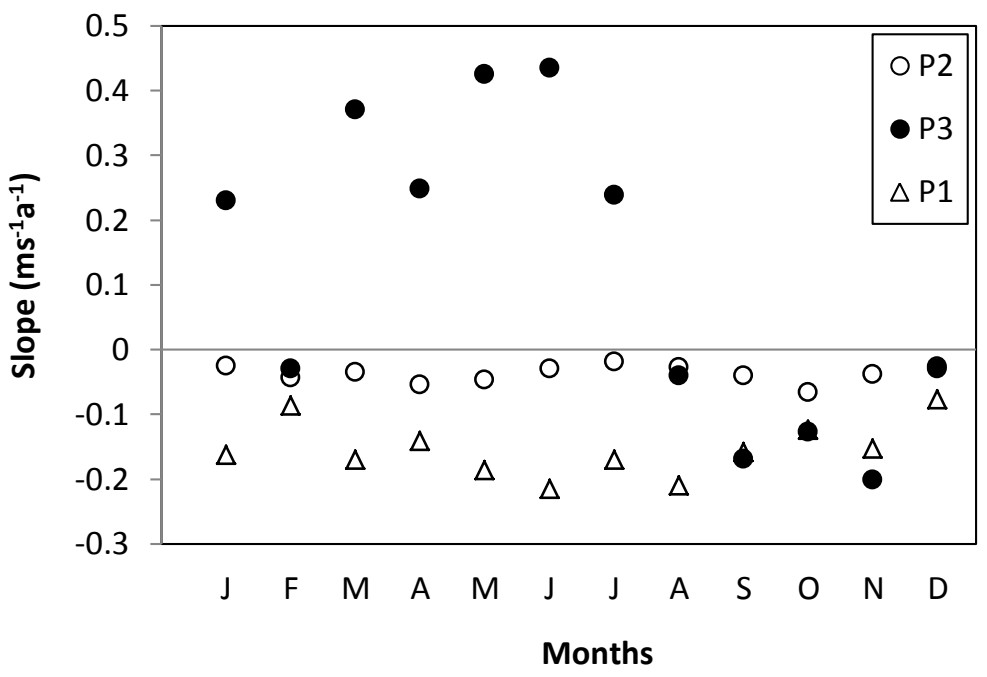

Fig 6:- Linear regression slopes between mean monthly of the maximum daily near-surface wind speeds and the years for each of the three sub-periods (P1 = 1961-1977; P2 = 1978-2008; P3 = 2009-2016) in Cotonou

\section{Changes in wind category occurrence:-}

Fig 7 sums up the distribution of wind categories according to Beaufort's scale for each of the three sub-periods. She shows that the occurrence of winds of types "Fresh breeze" to "Near gale" has decreased during the sub-period P2 compared to the sub-periods P1 and P3. In fact, winds of types "Fresh breeze ", "Strong breeze" and "Near gale" have respectively decreased from 34 to $9 \%$, from 17 to $3 \%$ and from 5 to $1 \%$ between P1 and P2. During the subperiod P3, these winds have made a revival and increased to 45\%, 22\% and 5\% exceeding their historical level of P1(1961-1977). In the opposite, the frequency of the winds of types "Gentle breeze" and "Moderate breeze" has increased during the sub-period P2 compared to sub-periods P1 and P3. Their occurrences were respectively 28\% and 57\% during sub-period P2 against 5\% and 37\% during P1 and 4\% and 21\% during P3. The overlapping of these variations with decennial trends of the daily wind speeds shows that the decrease of the winds between P1 and P2 and their revival between $\mathrm{P} 2$ and $\mathrm{P} 3$ are respectively due to the decrease and the increase in the occurrence of strong winds (Fresh breeze, Strong breeze and Near gale). 


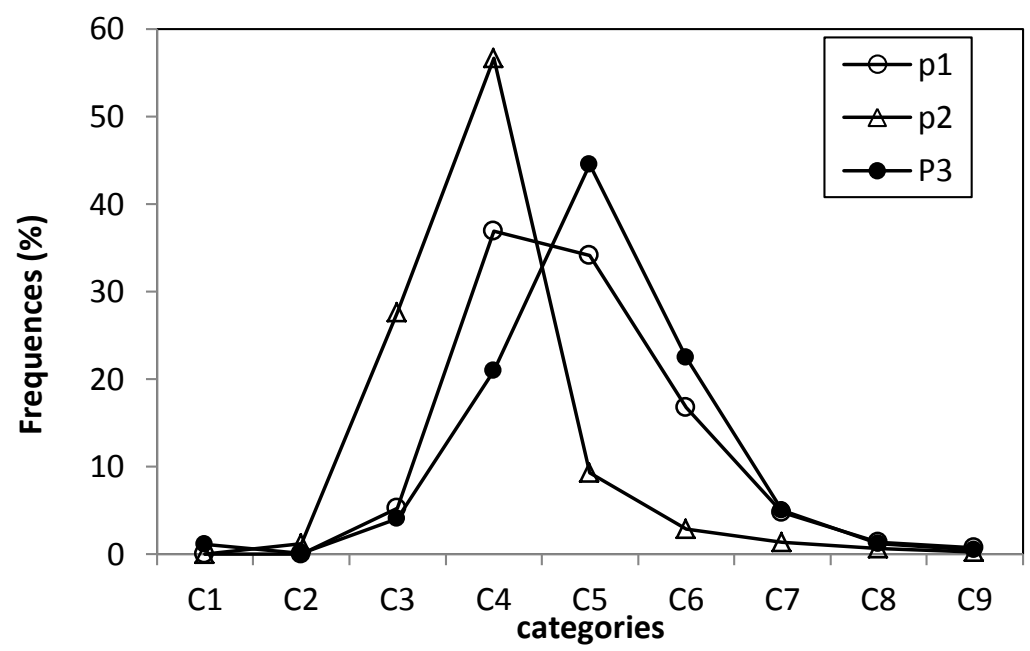

Fig 7:- Distribution of daily maximal wind speeds categories in Cotonou from 1961 to 2016. The categories have been defined according to Beaufort's scale (Table 1)

\section{Discussion and conclusion:-}

The decrease of winds between 1961 and 2008 observed in the South of Benin is similar to the trends of wind in other areas of the world. Pirazzoli and Tomasin (2003) have observed a sharp decrease in the wind speed between 1951 and the first half of the 1970s, with a reduction of this decrease during the 1980s and 1990s. Brazdil et al. (2009) have emphasized a gradual decrease of the wind speed between 1961 and 2001 in the Czech Republic. Tuller (2004) observed a reduction of the wind speed during the period situated between the end of the 1940s and the mid of 1990s. Pryor et al., (2009) showed a decrease of the winds in the USA between 1973 and 2005. McVicar et al., (2008) have noticed a reduction of the wind speed on almost 88\% of Australia between 1975 and 2006. Decreases of wind have also been noticed in China (Wang et al., 2004; Xu et al., 2006; Guo et al., 2011). These studies have generally shown declines between -0.004 and $-0.017 \mathrm{~ms}^{-1} \mathrm{a}^{-1}$ of the wind speed over these 50 last years similar the one observed in the South Benin (between -0.03 and $-0.15 \mathrm{~ms}^{-1} \cdot \mathrm{a}^{-1}$ ). However, slight increasing trends of the wind speeds $\left(0.005 \mathrm{~ms}^{-1} \cdot \mathrm{a}^{-1}\right)$ have also been noticed in some regions of the world, namely in Antarctic (Aristidi et al., 2005; Turner et al., 2005) and Alaska (Lynch et al., 2004). These trends match the results of the climate projection models that show a decrease and an increase of wind speeds respectively in the mid-latitude and high-latitude regions (Seidel et al., 2008; Yin, 2005). This tends to show that the trends of change in wind speed depend on the latitude under observation (McVicar et al., 2008). The length of the sub-period P3 under observation (8 years, 20092016) should make us more cautious in interpreting the trend of increasing wind speeds in the South of Benin starting in 2009. Nevertheless, this trend to a rise of the winds is similar to that reported by Pirazzoli and Tomasin (2003) over a part of Italy in the 80's. The changes in wind speeds observed in South Benin are essentially due to variations of the occurrences of strong winds. This result goes along with the one found in China by Guo et al., (2011). Although the trend of wind speed of South Benin goes along with the one observed in Europe, Asia and America, it does not apply to all of West Africa. In fact, Ozer (1996) hasn't observed a clear and neat trend of the wind speed when analyzing the evolution of the directions of the wind speeds from 1951 to 1994 on the Atlantic coast of West Africa from Southern Senegal to Northern Mauritania. As per the cause of the decrease of the wind speed, it is not well identified yet (Pryor et al., 2009). It might be linked to the decrease in the gradient of pressure between continents and oceans as a result of global warming (Lau et al., 2008; Huang et al., 2006; Nazarenko and Menon, 2005). 


\section{References:-}

1. Allé, C.S.U.Y., Vissoh, P.V., Guibert, H., Agbossou, K.E. and Afouda, A.A. (2013) : Relation entre perceptions paysannes de la variabilité climatique et observations climatiques au Sud-Bénin. VertigO, 13(3) : 14361, DOI : 10.4000/vertigo.14361.

2. Aristidi, E., Agabi, K., Azouit, M., Fossat, E., Vernin, J., Travouillon, T., Lawrence, J.S., Meyer, C., Storey, J.W.V., Halter, B., Roth, W.L. and Walden, V. (2005): An analysis of temperatures and wind speeds above Dome C, Antarctica. Astron. Astrophys., 430: 739-746.

3. Barbier, B., Yacouba, H., Karambiri, H., Zoromé, M. and Somé, B. (2009): Human vulnerability to climate variability in the Sahel: Farmer's adaptation strategies in Northern Burkina Faso. Environmental Management, 43: 790-803.

4. Brazdil, R., Chroma, K., Dobrovolny, P. and Tolasz, R., (2009): Climate fluctuations in the Czech Republic during the period 1961-2005. International Journal of Climatology, 29: 223-242, DOI: 10.1002/joc.1718.

5. Chamard, P.C. and Courel, M.F. (1988): Les vents et leur efficacité morphologique dans la région de Nouadhibou (Mauritanie). Publications de l'Association Internationale de Climatologie, 1: 123-130.

6. Fallot J.-M. and Hertig J.-A. (2008): Détermination des vents extrêmes à l'aide d'analyses statistiques et de modélisations numériques dans une topographie accidentée en Suisse. Bulletin de la Société géographique de Liège, 51: 31-47.

7. Gbaguidi, V.S., Gbaguidi, G.A., Adjovi, E., Amey, K., Zankpe, M., Danvi, A.-E. and Alodehou, E. (2011) : Cartographie des directions dominantes des vents au Bénin : outil de conception et de dimensionnement des ouvrages. J. Rech. Sci. Univ. Lomé (Togo), Série E, 13(1): 1-16.

8. Guo, H., Xu, M. and Hub, Q. (2011): Changes in near-surface wind speed in China: 1969-2005. Int. J. Climatol. 31: 349-358.

9. Hirsch, N., Hoffman, J. and Hontarrede, M. (2016): Petit manuel de météo marine. Glénat (www.glenatlivres.com), 191 p., ISBN 9782723481106.

10. Huang, J., Minnis, P., Lin, B., Wang, T., Yi, Y., Hu, Y., Sun-Marck, S. and Ayers, K. (2006): Possible influences of Asian dust aerosols on cloud properties and radiative forcing observed from MODIS and CERES. Geophysical Research Letters, 33: L06824, DOI: 10.1029/2005GL024724.

11. Kalu, A.E. (1979): The African dust plume: Its characteristics and propagation across West Africa in winter. In: Morales D, (Ed) Saharan dust: Mobilization, transport, deposition. Wiley: Scope 14, pp. 95-118.

12. Lamb, P.J. (1982): Persistence of Subsaharan drought. Nature, 299: 46-47.

13. Lau, K.M., Ramanathan, V., Wu, G., Li, Z., Tsay, S.C., Hsu, C., Sikka, R., Holben, B., Lu, D., Tartari, G., Chin, M., Koudelova, P., Chen, H., Ma, Y., Huang, J., Taniguchi, K. and Zhang, R. (2008): The joint aerosolmonsoon experiment - a new challenge for monsoon climate research. Bulletin of the American Meteorological Society, 3: 369-383, DOI: 10.1175/BAMS-89-3-369.

14. Lynch, A.H., Curry, J.A., Brunner, R.D. and Maslanik, J.A. (2004): Toward an integrated assessment of the impacts of extreme wind events on Barrow, Alaska. Bull. Am. Meteorol. Soc., 85: 209-221.

15. Mann, H.B. and Whitney, D.R. (1947): On a test of whether one of two random variables is stochastically larger than the other. Ann. Math. Stat., 18(1): 50-60, DOI: 10.1214/aoms/1177730491.

16. McTainsh, G.H. (1980): Harmattan dust deposition in northern Nigeria. Nature, 286: 587-588.

17. McVicar, T.R., Van Niel, T.G., Li, L.T., Roderick, M.L., Rayner, D.P., Ricciardulli, L. and Donohue, R.J. (2008): Wind speed climatology and trends for Australia, 1975-2006: Capturing the stilling phenomenon and comparison with near-surface reanalysis output. Geophys. Res. Lett., 35: L20403, DOI: 10.1029/2008GL035627.

18. Nazarenko, L. and Menon, S. (2005): Varying trends in surface energy fluxes and associated climate between 1960 and 2002 based on transient climate simulations. Geophysical Research Letters 32: L22704, DOI: 10.1029/2005GL024089.

19. Ozer, P. (1997): Evolution des directions et des vitesses des vents de 1951 à 1994 sur la façade Atlantique de l'Afrique de l'Ouest du Sud du Sénégal au Nord de la Mauritanie. Publications de l'Association Internationale de Climatologie, 9: 479-486.

20. Pettitt, A.N. (1979): A non-parametric approach to the change-point problem. Appl. Statist., 28(2): 126-135.

21. Pirazzoli, P.A. and Tomasin, A. (2003): Recent near-surface wind changes in the central Mediterranean and Adriatic areas. Int. J. Climatol., 23: 963-973.

22. Pryor, S.C., Barthelmie, R.J., Young, D.T., Takle, E.S., Arritt, R.W., Flory, D., Gutowski Jr., W.J., Nunes, A. and Roads, J. (2009): Wind speed trends over the contiguous United States. J. Geophys. Res., 114: D14105, DOI: $10.1029 / 2008 J D 011416$. 
23. Roderick, M.L., Rotstayn, L.D., Farquhar, G.D. and Hobbins, M. T. (2007): On the attribution of changing pan evaporation. Geophys. Res. Lett., 34: L17403, DOI: 10.1029/2007GL031166.

24. Seidel, D.J., Fu, Q., Randel, W.J. and Reichler, T.J. (2008): Widening of the tropical belt in a changing climate. Nature Geosci., 1: 21-24.

25. Shenbin, C., Yunfeng, L. and Thomas, A. (2006): Climatic change on the Tibetan Plateau: Potential evapotranspiration trends from 1961 - 2000. Clim. Change, 76: 291-319.

26. Smits, A., Klein Tank M.G. and Koennen P. (2005): Trends in storminess over the Netherlands, $1962-2002$. International Journal of Climatology, 25: 1331-1344.

27. Sultan, B., Alhassane, A., Barbier, B., Baron, C., Bella-Medjo Tsogo, M., Berg, A., Dingkuhn, M., Fortilus, J., Kouressy, M., Leblois, A., Marteau, R., Muller, B., Oettli, P., Quirion, P., Roudier, P., Traoré, SB. and Vaksmann, M. (2012): La question de la vulnérabilité et de l'adaptation de l'agriculture sahélienne au climat au sein du programme AMMA. La Météorologie, Spécial AMMA: 64-72.

28. Tuller, S.E., (2004): Measured wind speed trends on the west coast of Canada. Int. J. Climatol., 24: 1359-1374.

29. Turner, J., Colwell, S.R., Marshall, G.J., Lachlan-Cope, T.A., Carleton, A. M., Jones, P.D., Lagun, V., Reid, P.A. and Iagovkina, S. (2005): Antarctic climate change during the last 50 years. Int. J. Climatol., 25: $279-294$.

30. Wang, J., Ding, Y., He, Z. and Yu, J. (2004): An updating analysis of the climate change in recent 50 years. Acta Meteorologica Sinica, 62(2): 228-236.

31. Xu, M., Chang, C., Fu, C., Qi, Y., Robock, A., Robinson, D. and Zhang, H. (2006): Steady decline of east Asian monsoon winds, 1969-2000: evidence from direct ground measurements of wind speed. Journal of Geophysical Research: Atmospheres 111: D24111, DOI: 10.1029/2006JD007337.

32. Yin, J.H. (2005): A consistent poleward shift of the storm tracks in simulations of $21^{\text {st }}$ century climate. Geophys. Res. Lett., 32: L18701, DOI:10.1029/2005GL023684.

33. Zhang, Y.Q., Liu, C.M., Tang, Y.H. and Yang, Y.H. (2007): Trends in pan evaporation and reference and actual evapotranspiration across the Tibetan Plateau. Journal of Geophysical Research: Atmospheres 112: D12110, DOI: $10.1029 / 2006 J D 008161$.

34. Zhou W., Yang H. and Fang Z. (2006): Wind power potential and characteristic analysis of the Pearl River Delta region, China. Renewable Energy 31: 739-753. 
